\title{
Evaluation of Physicochemical and Thermal Properties of the Consciousness Energy Healing Treated Tellurium
}

ISSN: 2576-8816

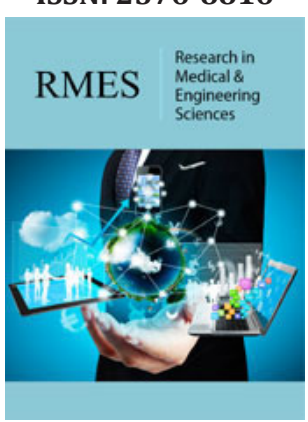

*Corresponding author: Snehasis Jana, Trivedi Science Research Laboratory Pvt Ltd, India.

\section{Submission: 侮- May 28, 2019}

Published: 眥July 22, 2019

Volume 8 - Issue 1

How to cite this article: Dahryn $\mathrm{T}$, Mahendra K T, Alice B, Gopal G, Snehasis J. Evaluation of Physicochemical and Thermal properties of the Consciousness Energy Healing Treated Tellurium. Res Med Eng Sci. 8(1).RMES.000678.2019. DOI: 10.31031/RMES.2019.08.000678

Copyright@ Dahryn Trivedi, This article is distributed under the terms of the Creative Commons Attribution 4.0 International License, which permits unrestricted use and redistribution provided that the original author and source are credited.

\author{
Dahryn Trivedi ${ }^{1}$, Mahendra Kumar Trivedi $^{1}$, Alice Branton ${ }^{1}$, Gopal Nayak ${ }^{1}$ and \\ Snehasis Jana ${ }^{2 *}$ \\ ${ }^{1}$ Trivedi Global, Inc, Henderson, USA \\ ${ }^{2}$ Trivedi Science Research Laboratory Pvt Ltd, India
}

\begin{abstract}
Tellurium (Te) is used in the heavy industry for the preparation of alloys, pigments, rubber, etc. and could be used as a new class of anti-inflammatory drugs. This study was performed to determine the changes in the physicochemical and thermal properties of tellurium that might result due to the impact of the Trivedi Effect $^{\circledR}$-Energy of Consciousness Healing Treatment. For this, the sample was divided into the control (not given Biofield Energy Treatment) and treated parts that received the Trivedi Effect ${ }^{\circledR}$-Biofield Energy Healing Treatment, remotely, by a renowned Biofield Energy Healer, Dahryn Trivedi. The data showed the significant impact of the Biofield Energy Treatment on the particle sizes of the treated tellurium at $d_{10}, d_{50}, d_{90}$, and $D(4,3)$ that were decreased by $26.09 \%, 30.63 \%, 21.72 \%$, and $24.98 \%$, respectively, compared to the control sample. The treated tellurium showed an increase in the specific surface area by $38.89 \%$ compared with the control sample. The PXRD peak intensities of the treated tellurium were altered ranging from $-32.00 \%$ to $7.00 \%$; while the crystallite sizes were decreased ranging from $10.25 \%$ to $38.49 \%$, along with $23.59 \%$ decrease in the average crystallite size, compared to the control sample. The total weight loss was decreased after the thermal degradation by $2.88 \%$; however, the residue weight was increased by $5.25 \%$, compared to the control sample. Similarly, the maximum thermal degradation temperature of the treated tellurium showed a significant increase by $2.83 \%\left(\sim 16^{\circ} \mathrm{C}\right)$ than the control sample. Thus, the overall study showed the ability of the Biofield Energy Treatment in changing the physicochemical and thermal properties of the tellurium sample as compared to the control sample. Therefore, the Trivedi Effect ${ }^{\circledR}$-Consciousness Energy Healing Treatment could be considered an important approach for improving the solubility, dissolution, bioavailability, and thermal stability of tellurium sample. Besides, the treated tellurium could be more useful for many industrial applications, i.e., metallurgy (in iron, stainless steel, copper, and lead alloys), pigments for ceramics, cadmium telluride solar panels, glass optical fibres for telecommunications, vulcanization of rubber, blasting caps, catalysts for the heterogeneous reactions, production of iodine-131, etc.
\end{abstract}

Keywords: Tellurium; The Trivedi Effect ${ }^{\circledR}$; Energy of Consciousness Healing Treatment; PSA; PXRD; TGA

\section{Introduction}

Tellurium (Te) was discovered in 1782 by F. J. Mueller von Reichenstein from ores mined in the gold districts of Transylvania and the name was taken from the Latin word "tellus", which means "earth" [1]. There were both the inorganic and organic derivatives of tellurium in which the organotellurium compounds could be divided into two distinct groups based on the oxidation state of tellurium. The first group of organotellurium compounds is the divalent derivatives of tellurium. In this, there are tellurols that seemed analogues of alcohols and thiols and further oxidized to ditellurides. Moreover, the di-organo- tellurides are considered as the analogues of ethers and tio-ethers, which comprise most of the organotellurium compounds studied till date. The other category in this class is di-organo-ditellurides that are products of oxidation of tellurols and thus related to peroxides. The second group of organotellurium compounds is the hypervalent derivatives with the oxidation states of +4 and +6 . This group contains the classes of organotellurium trihalides, di-organo-tellurium dihalides, organo-tellurates, organotellurium oxides, and organopertelluranes [2,3]. The biological use of tellurium was mentioned in history in the treatment of microbial infections before the discovery of antibiotics. Some early studies done in 1926 reported its use in the 
treatment of leprosy and syphilis [4]. In now days, the research studies reported that the organotellurane compound RT-01 has shown toxic effects against promastigotes and amastigotes [5]. The telluride nanoparticles containing cadmium could be used as quantum dots in diagnosis and imaging as they are fluorescent in nature. Some of the organotelluranes such as, 2-naphthyl diorganyltellurium dichloride's was known to possess the gramnegative antibacterial effect. Some studies also reported the antioxidant effects of organotellurides and diorganoditellurides, as well as the immunomodulatory effects of the inorganic tellurane (AS-101) and organic telluranes as protease inhibitors [3]. It was studied that the compound AS101 and other Te (IV) compounds worked by specifically inactivating the cysteine proteases, while they do not pose any effect on the other families of serine, metalloproteases, and aspartic. The effects of the inorganic tellurium complexes, such as, AS101 and SAS are primarily caused by their specific Te(IV) redox-modulating activities that resulted in the inhibition of specific tumor survival proteins like survivin, inactivation of cysteine proteases such as cathepsin B, or obstruction of tumor IL-10 production [6]. The positive effect of AS101 has also been seen in animal models of Parkinson's disease, where it protects the dopaminergic neurons and thereby helps in improving the motor function [7]. It also induced PC12 differentiation and thereby protects the neurons from apoptotic death [8]. AS101 has also been found to be a novel inhibitor of IL1 beta converting enzyme (caspase-1) and it inhibits the production of IL-10, IFN- $\gamma$, IL-2R, and IL5 [9]. It also helps in protecting the bone marrow stem cells during chemotherapy [10]. In recent days the research studies reported some other pharmacological activities of AS-101, such as the induction of hair growth in both nude mice and in teenagers with alopecia [11]; the enhancement of neuronal survival in an ischemic stroke animal model [12]; and protection against homocysteine-promoted apoptosis [13]. Te (IV) compounds also affect the redox biological activity taken place in the human body and hence could be used as a new class of anti-inflammatory compounds [14]. Besides, tellurium have many industrial applications, i.e., metallurgy (in iron, stainless steel, copper, and lead alloys), pigments for ceramics, cadmium telluride (CdTe) solar panels, glass optical fibres for telecommunications, vulcanization of rubber, blasting caps, catalysts for the heterogeneous reactions, production of iodine-131 by neutron bombardment, etc [15].

In these days, various researches have been done to improve the drug performance within the body by changing the physicochemical properties, such as the particle size, crystalline structure, and surface area, etc. $[16,17]$. The Biofield Energy Treatment is also a novel approach that is used by various researchers for altering the properties of various compounds as it could pose significant effect on the living and non-living objects $[18,19]$. It is since every living organism possesses unique energy surrounding its body in the form of electromagnetic field, which is infinite and paradimensional and known as Biofield Energy. The Complementary and Alternative Medicine (CAM) specifies the use of Biofield energy as an energy medicine that involves the use of traditional as well as contemporary models to cure various diseases [20-22]. The
Trivedi Effect ${ }^{\circledR}$ is also considered as a natural and scientifically proven process that involves harnessing this inherently intelligent energy by a person, which can further be transmitted through the possible mediation of neutrinos, anywhere on the planet [23]. Various studies reported the significant effect of the Trivedi Effect ${ }^{\circledR}$ Consciousness Energy Healing Treatment in the area of metals and ceramics $[24,25]$, biotechnology [26,27], human health and wellness [28-30], agriculture science [31,32], microbiology [3335], and livestock [36]. Also, it has been reported for its significant impact on the physicochemical and thermal properties of various organic, pharmaceutical, and nutraceutical compounds [37-39]. Thus, this study was done to analyse the effect of the Trivedi Effect ${ }^{\circledR}$ Consciousness Energy Healing Treatment on the physicochemical and thermal properties of tellurium by using various sophisticated analytical techniques.

\section{Materials and Methods}

\section{Chemicals and reagents}

The test sample tellurium was purchased from Sigma Aldrich, USA and other chemicals used in the experiments were purchased in India.

\section{Consciousness energy healing treatment strategies}

In this study, the tellurium was used as the test compound that was divided into the control and treated parts. The control sample was not given any treatment; whereas, the treated part remotely received the Energy of Consciousness Healing Treatment by the renowned Biofield Energy Healer, Dahryn Trivedi (USA). The treatment method involves keeping the sample under the standard laboratory conditions followed by providing the Trivedi Effect ${ }^{\circledR}$ by the Biofield Energy Healer for 3 minutes through the Unique Energy Transmission process. Besides, the control sample was subjected to a "sham" healer under same laboratory conditions, who did not have any knowledge about the Biofield Energy Healing Treatment. After that, the control and the Biofield Energy Treated samples were kept in similar sealed conditions and further characterized by using sophisticated analytical techniques.

\section{Characterization}

The particle size distribution (PSD) analysis was performed with the help Malvern Mastersizer 2000, from the UK using the wet method $[40,41]$. The X-ray diffraction (PXRD) analysis of tellurium powder was achieved with the help of Rigaku MiniFlex-II Desktop X-ray diffractometer (Japan) $[42,43]$. The average crystallite size was calculated using the Scherrer's formula (1)

$$
\mathrm{G}=\mathrm{k} \lambda / \beta \cos \theta
$$

Where $\mathrm{G}$ is the crystallite size ( $\mathrm{nm}$ ), $\mathrm{k}$ is the equipment constant, $\lambda$ is the radiation wavelength, $\beta$ is the full-width half maximum, and $\theta$ is the Bragg angle [44].

Similarly, the thermal gravimetric analysis (TGA) thermograms of tellurium were obtained with the help of TGA Q50 TA instruments $[40,41]$. The $\%$ change in specific surface area (SSA), particle size, 
peak intensity, crystallite size, weight loss and the maximum thermal degradation temperature $\left(\mathrm{T}_{\max }\right)$ of the Biofield Energy Treated tellurium was calculated compared with the control sample using the following equation 2 :

$$
\% \text { change }=\frac{[\text { Treated }- \text { Control }]}{\text { Control }} \text { X100 (2) }
$$

\section{Results and Discussion}

\section{Particle Size Analysis (PSA)}

Table 1: The particle size distribution of the control and treated tellurium.

\begin{tabular}{|c|c|c|c|c|c|}
\hline Parameter & $\mathbf{d}_{\mathbf{1 0}}(\boldsymbol{\mu m})$ & $\mathbf{d}_{\mathbf{5 0}}(\boldsymbol{\mu m})$ & $\mathbf{d}_{\mathbf{9 0}}(\boldsymbol{\mu m})$ & $\mathbf{D}(\mathbf{4}, \mathbf{3})(\boldsymbol{\mu m})$ & $\mathbf{S S A}\left(\mathbf{m}^{2} / \mathbf{g}\right)$ \\
\hline Control & 7.59 & 28.21 & 73.93 & 35.15 & 0.36 \\
\hline Biofield Energy Treated & 5.61 & 19.57 & 57.87 & 26.37 & 0.5 \\
\hline Percent change* $(\%)$ & -26.09 & -30.63 & -21.72 & -24.98 & 38.89 \\
\hline
\end{tabular}

$\mathrm{d}_{10}, \mathrm{~d}_{50}$, and $\mathrm{d}_{90}$ : particle diameter corresponding to $10 \% 50 \%$ and $90 \%$ of the cumulative distribution, $\mathrm{D}(4,3)$ : the average mass-volume diameter, and SSA: the specific surface area. "denotes the percentage change in the Particle size distribution of the treated tellurium with respect to the control sample.

The particle size analysis was done to find out the difference in the treated tellurium compared to the control sample in terms of the particle size distribution after the Biofield Energy treatment. The results showed the significant reduction in the particle size of the treated tellurium corresponding to $d_{10}, d_{50}, d_{90^{\prime}}$ and $D(4,3)$ by $26.09 \%, 30.63 \%, 21.72 \%$, and $24.98 \%$, respectively as compared to the control sample (Table 1).

The study also revealed that the SSA of the treated tellurium was significantly increased by $38.89 \%$ compared with the SSA of the control sample. Various studies reported the significant impact of the specific surface area on the solubility profile of the drug $[45,46]$. The scientific studies claimed that the increased effective surface area of drug due to its reduced particle size ultimately increases the salvation process that helps in increasing the solubility of the compound as well as its bioavailability within the body [47]. Hence, it was presumed that the treated tellurium might show better solubility and bioavailability as compared to the control sample.

\section{Powder X-ray Diffraction (PXRD) analysis}

The diffractograms observed from the PXRD analysis of the control and treated samples (Figure 1) showed the sharp and intense peaks that indicated the crystalline nature of both the samples. The analysis of both the diffractograms indicated the significant changes in the peak intensities and the crystallite sizes of the treated tellurium as compared to the control sample. The intensities corresponding to the characteristic peaks of the treated tellurium were altered ranging from $-32.00 \%$ to $7.00 \%$; while the crystallites sizes were decreased ranging from $10.25 \%$ to $38.49 \%$, compared to the control sample (Table 2; Figure 1).

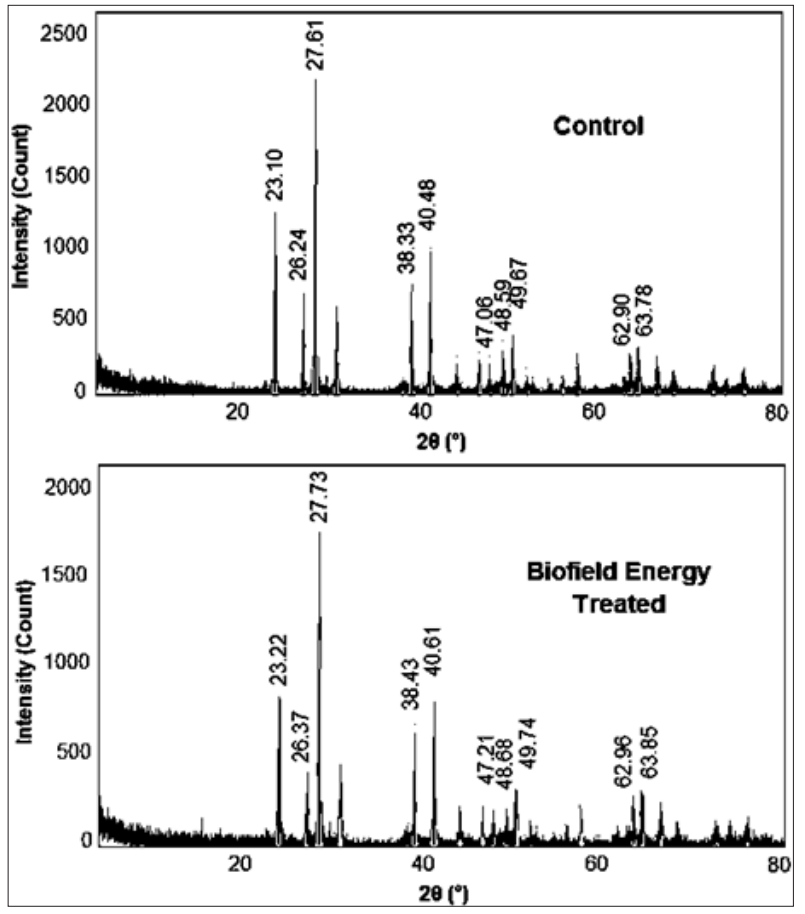

Figure 1: PXRD diffractograms of the control and treated tellurium. 
Table 2: PXRD data for the control and treated tellurium.

\begin{tabular}{|c|c|c|c|c|c|c|c|c|}
\hline \multirow{2}{*}{ Entry No. } & \multirow{2}{*}{$\begin{array}{c}\text { Bragg angle }\left({ }^{\circ} 2 \theta\right) \\
\text { Control }\end{array}$} & \multicolumn{4}{|c|}{ Intensity (cps) } & \multicolumn{3}{|c|}{ Crystallite Size (G, nm) } \\
\hline & & Treated & Control & Treated & $\%$ Change $^{a}$ & Control & Treated & $\%$ Change $^{b}$ \\
\hline 1 & 23.1 & 23.22 & 150 & 133 & -11.33 & 504 & 310 & -38.49 \\
\hline 2 & 26.24 & 26.37 & 69 & 53.3 & -22.75 & 450 & 298 & -33.78 \\
\hline 3 & 27.61 & 27.73 & 337 & 317 & -5.93 & 448 & 298 & -33.48 \\
\hline 4 & 38.33 & 38.43 & 123 & 116 & -5.69 & 474 & 332 & -29.96 \\
\hline 5 & 40.48 & 40.61 & 182 & 158 & -13.19 & 359 & 298 & -16.99 \\
\hline 6 & 47.06 & 47.21 & 24.3 & 26 & 7 & 488 & 397 & -18.65 \\
\hline 7 & 48.59 & 48.68 & 50 & 34 & -32 & 356 & 261 & -26.69 \\
\hline 8 & 49.67 & 49.74 & 79 & 65.8 & -16.71 & 439 & 394 & -10.25 \\
\hline 9 & 62.9 & 62.96 & 48 & 41.1 & -14.38 & 511 & 445 & -12.92 \\
\hline 10 & 63.78 & 63.85 & 51 & 47.8 & -6.27 & 435 & 378 & -13.1 \\
\hline
\end{tabular}

${ }^{a}$ denotes the percentage change in the peak intensity of treated tellurium with respect to the control sample; ${ }^{b}$ denotes the percentage change in the crystallite size of treated tellurium with respect to the control sample.

The treated tellurium also showed a significant change in the average crystallite size $(341.10 \mathrm{~nm})$ that was found to be decreased by $23.59 \%$ as compared to the control sample $(446.40 \mathrm{~nm})$. Such remarkable changes observed in the Bragg's angles of the characteristic peaks as well as the peak intensities and crystallite sizes of the treated tellurium might indicate the possible alterations in the crystalline properties of tellurium after the Biofield Energy Treatment.

The alterations in the Bragg's angles of the characteristic peaks as well as their corresponding peak intensities and crystallite sizes could be considered as a basis for altered crystalline properties of the compound $[48,49]$. Such changes are also reported previously by various researchers that could happen after the Biofield Energy Treatment. Thus, this analysis also indicated the altered crystalline properties of the treated tellurium as compared to the control sample that might occur due to the formation of a new polymorph of tellurium. Such physical alterations in the crystalline structure of compounds may improve the bioavailability and efficacy of the drug [50]. Thus, the Biofield Energy Treatment might be considered as an approach that affects the crystalline properties of tellurium and might make it more suitable for the pharmaceutical and metal industry application point of view compared to the control sample.

\section{Thermal Gravimetric Analysis (TGA)/ Differential} Thermogravimetric Analysis (DTG)

The TGA thermograms of both the samples, i.e., the control and treated tellurium were shown in Figure 2 that indicated the significant weight loss of tellurium sample during the thermal degradation. The data revealed that the total weight loss of the treated tellurium during the thermal heating was decreased by $2.88 \%$ than the control sample. However, the residue weight of the treated tellurium was observed to be increased by $5.25 \%$ as compared to the control sample (Table 3; Figure $2 \& 3$ ).
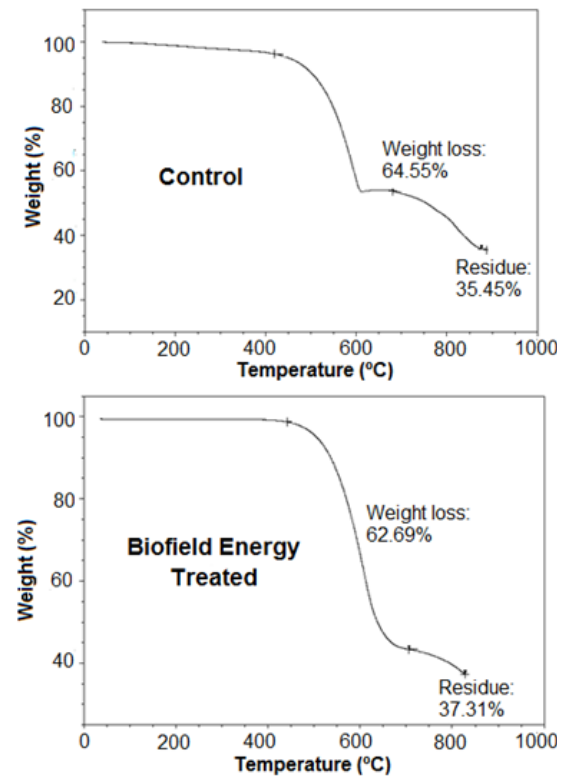

Figure 2: TGA thermograms of the control and treated tellurium. 

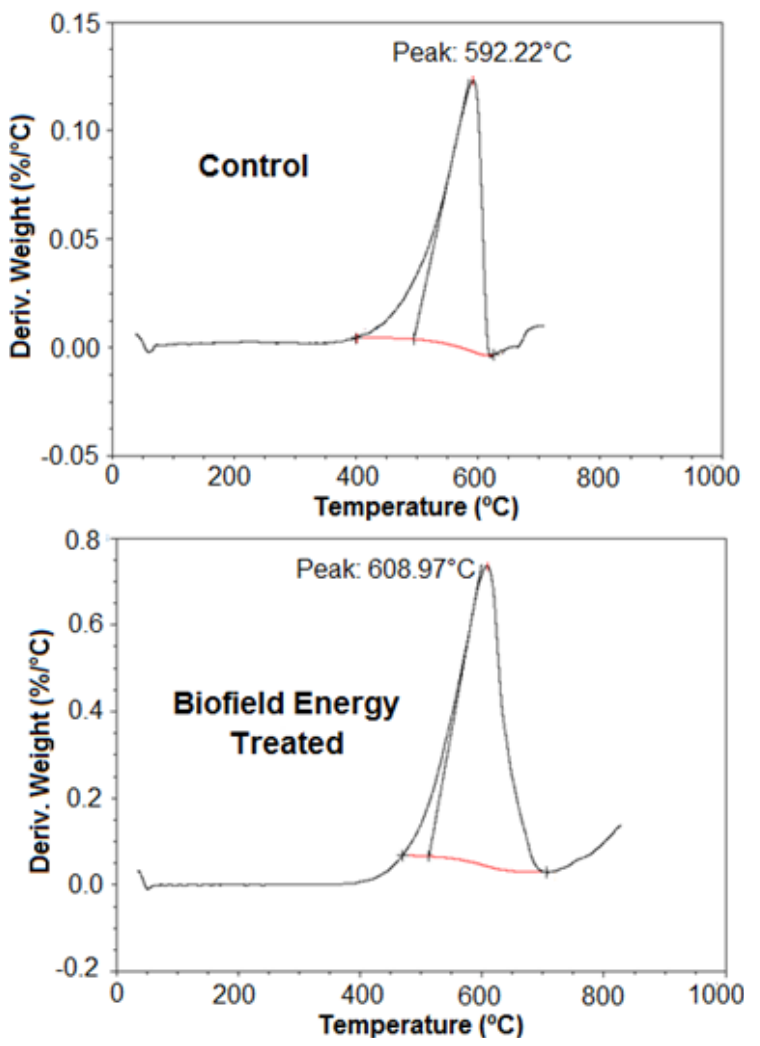

Figure 3: DTG thermograms of the control and treated tellurium.

Table 3: TGA/DTG data of the control and treated samples of tellurium.

\begin{tabular}{|c|c|c|c|}
\hline \multirow{2}{*}{ Sample } & \multicolumn{2}{|c|}{ TGA } & DTG \\
\cline { 2 - 4 } & Total weight loss (\%) & Residue \% & T $_{\max }$ ( ${ }^{\circ} \mathbf{C}$ ) \\
\hline Control & 64.55 & 35.45 & 592.22 \\
\hline Biofield Energy Treated & 62.69 & 37.31 & 608.97 \\
\hline \% Change* & -2.88 & 5.25 & 2.83 \\
\hline
\end{tabular}

*denotes the percentage change of the treated tellurium with respect to the control sample,

$\mathrm{T}_{\max }=$ the temperature at which maximum weight loss takes place in TG or peak temperature in DTG.

The DTG data (Table 3) of both the samples showed differences in their $\mathrm{T}_{\max }$ The tellurium sample showed a significant increase in its $\mathrm{T}_{\max }$ by $2.83 \%$, which is $\sim 16^{\circ} \mathrm{C}$ compared to the control sample. Hence, the overall TGA/DTG data showed that the thermal stability of the tellurium sample was increased after the Biofield Energy Treatment as compared to the control sample.

\section{Conclusion}

The impact of the Trivedi Effect ${ }^{\circledR}$-Consciousness Energy Healing Treatment on the physicochemical and thermal properties of different compounds has been reported in this scientific study. The treated tellurium showed a significant decrease in the particle sizes at $d_{10}, d_{50}, d_{90}$, and $D(4,3)$ by $26.09 \%, 30.63 \%, 21.72 \%$, and $24.98 \%$, respectively, as compared to the control sample. The impact on the particle size distribution of the treated tellurium also resulted in an increase in specific surface area after the Biofield Energy Treatment that was observed to be increased by $38.89 \%$ than the control sample. The PXRD peak intensities of the Biofield Energy Treated tellurium were altered ranging from
$-32.00 \%$ to $7.00 \%$; while the crystallite sizes were decreased ranging from $10.25 \%$ to $38.49 \%$, along with $23.59 \%$ decrease in the average crystallite size, compared to the control sample. The total weight loss was decreased after the thermal degradation by $2.88 \%$; however, the residue weight was increased by $5.25 \%$ in the Biofield Energy Treated tellurium compared to the control sample. Similarly, the maximum thermal degradation temperature of the Biofield Energy Treated tellurium showed a significant increase by $2.83 \%\left(\sim 16^{\circ} \mathrm{C}\right)$ than the control sample. Thus, it indicated the increased thermal stability of the Biofield Energy Treated tellurium after the Biofield Energy Treatment. Therefore, the overall analysis revealed the impact of the Biofield Energy Treatment on the physicochemical and thermal properties of tellurium sample that resulted in decreased particle sizes, increased specific surface area, and altered crystalline properties, which might improve the solubility, dissolution, and bioavailability as well as the thermal stability of the treated tellurium in comparison to the control sample. Thus, the Biofield Energy Treated tellurium might be used as a novel approach in formulation development for improving the 
bioavailability, efficacy and thermal stability of drug to fight against various diseases and disorders. Besides, the treated tellurium could be more useful for many industrial applications, i.e., metallurgy (in iron, stainless steel, copper, and lead alloys), pigments for ceramics, cadmium telluride (CdTe) solar panels, glass optical fibers for telecommunications, vulcanization of rubber, blasting caps, catalysts for the heterogeneous reactions, production of iodine-131, etc.

\section{Acknowledgements}

The authors are grateful to Central Leather Research Institute, SIPRA Lab. Ltd., Trivedi Science, Trivedi Global, Inc., Trivedi Testimonials, and Trivedi Master Wellness for their assistance and support during this work.

\section{References}

1. Bragnall KW (1966) The chemistry of selenium, tellurium, and polonium. Elsevier Publishing Cop, London.

2. Cooper WC (1971) Tellurium. Van Nostrand Reinhod Cop, New York, USA.

3. Cunha RLOR, Gouvea IE, Juliano L (2009) A glimpse on biological activities of tellurium compounds. An Acad Bras Cienc 81(3): 393-407.

4. Demeio RH, Henriques FC (1947) Tellurium, excretion and distribution in tissues studied with a radioactive isotope. J Biol Chem 169(3): 609623.

5. Lima CBC, Arrais Silva WW, Oliveira RL, Cunha R, Giorgio S (2009) A novel organotellurium compound (RT-01) as a new antileishmanial agent. Korean J Parasitol 47: 213-218.

6. Sredni B (2012) Immunomodulating tellurium compounds as anticancer agents. Semin Cancer Biol 22(1): 60-69.

7. Sredni B, Geffen R, Duan W, Albeck M, Shalit F, et al. (2007) Multifunctional tellurium molecule protects and restores dopaminergic neurons in Parkinson's disease models. The FASEB J 21(8): 1870-1883.

8. Makarovsky D, Kalechman Y, Sonino T, Freidkin I, Teitz S, et al. (2003) Tellurium compound AS101 induces PC12 differentiation and rescues the neurons from apoptotic death. Ann N Y Acad Sci 1010: 659-666.

9. Brodsky M, Yosef S, Galit R, Albeck M, Longo DL, et al. (2007) The synthetic tellurium compound, AS101, is a novel inhibitor of IL-1beta converting enzyme. J Interferon Cytokine Res 27(6): 453-462.

10. Guest I, Uetrecht J (2001) Bone marrow stem cell protection from chemotherapy by low molecular weight compounds. Exp Hematol 29(2): 123-137.

11. Sredni B, Gal R, Cohen IJ, Dazard JE, Givol D, et al. (2004) Hair growth induction by the tellurium immunomodulator AS101: association with delayed terminal differentiation of follicular keratinocytes and rasdependent up-regulation of KGF expression. FASEB J 18(2): 400-402.

12. Okun E, Dikshtein Y, Carmely A, Saida H, Frei G, et al. (2007) The organotellurium compound ammonium trichloro(dioxoethylene-o,o') tellurate reacts with homocysteine to form homocystine and decreases homo-cysteine levels in hyperhomocysteinemic mice. FEBS J 274(12): 3159-3170.

13. Okun E, Arumugam TV, Tang SC, Gleichmann M, Albeck M, et al. (2007) The organotellurium compound ammonium trichloro (dioxoethylene-0,0') tellurate enhances neuronal survival and improves functional outcome in an ischemic stroke model in mice. J Neurochem 102(4): 1232-1241.

14. Brodsky M, Halpert G, Albeck M, Sredni B (2010) The anti-inflammatory effects of the tellurium redox modulating compound, AS101, are associated with regulation of NFêB signaling pathway and nitric oxide induction in macrophages. J Inflammation 7(1): 3.

15. https://en.wikipedia.org/wiki/Tellurium.

16. Barlow RB (1974) Physicochemical properties and biological activity: thermodynamic properties of compounds related to acetylcholine assessed from depression of freezing-point and enthalpies of dilution. Br J Pharmacol 51(3): 413-426.

17. Braakhuis HM, Park MV, Gosens I, De Jong WH, Cassee FR (2014) Physicochemical characteristics of nanomaterials that affect pulmonary inflammation. Part Fibre Toxicol 11: 18.

18. Trivedi MK, Branton A, Trivedi D, Nayak G, Sethi KK, et al. (2016) Isotopic abundance ratio analysis of biofield energy treated indole using gas chromatography-mass spectrometry. Science Journal of Chemistry 4: 41-48.

19. Koster DA, Trivedi MK, Branton A, Trivedi D, Nayak G, et al. (2018) Evaluation of biofield energy treated vitamin $\mathrm{D}_{3}$ on bone health parameters in human bone osteosarcoma cells (MG-63). Biochemistry and Molecular Biology 3: 6-14.

20.Guarneri E, King RP (2015) Challenges and opportunities faced by biofield practitioners in global health and medicine: A white paper. Global Advances in Health and Medicine 4: 89-96.

21. Barnes PM, Bloom B, Nahin RL (2008) Complementary and alternative medicine use among adults and children: United States, 2007. Natl Health Stat Report 12: 1-23.

22. Frass M, Strassl RP, Friehs H, Müllner M, Kundi M, et al. (2012) Use and acceptance of complementary and alternative medicine among the general population and medical personnel: A Systematic Review. Ochsner J 12(1): 45-56.

23. Trivedi MK, Mohan TRR (2016) Biofield energy signals, energy transmission and neutrinos. American Journal of Modern Physics 5(6): 172-176.

24. Trivedi MK, Tallapragada RM, Branton A, Trivedi D, Nayak G, et al. (2015) Analysis of physical, thermal, and structural properties of biofield energy treated molybdenum dioxide. International Journal of Materials Science and Applications 4(5): 354-359.

25. Trivedi MK, Tallapragada RM, Branton A, Trivedi D, Nayak G, et al. (2015) The potential impact of biofield energy treatment on the physical and thermal properties of silver oxide powder. International Journal of Biomedical Science and Engineering 3(5): 62-68.

26. Nayak G, Altekar N (2015) Effect of biofield treatment on plant growth and adaptation. J Environ Health Sci 1: 1-9.

27. Branton A, Jana S (2017) The influence of energy of consciousness healing treatment on low bioavailable resveratrol in male Sprague Dawley rats. International Journal of Clinical and Developmental Anatomy 3(3): 9-15.

28. Kinney JP, Trivedi MK, Branton A, Trivedi D, Nayak G, et al. (2017) Overall skin health potential of the biofield energy healing based herbomineral formulation using various skin parameters. American Journal of Life Sciences 5(2): 65-74.

29. Branton A, Jana S (2017) Effect of The biofield energy healing treatment on the pharmacokinetics of 25-hydroxyvitamin D3 [25(OH)D3] in rats after a single oral dose of vitamin D3. American Journal of Pharmacology and Phytotherapy 3(2): 11-18.

30. Singh J, Trivedi MK, Branton A, Trivedi D, Nayak G, et al. (2017) Consciousness energy healing treatment based herbomineral formulation: a safe and effective approach for skin health. American Journal of Pharmacology and Phytotherapy 2(1): 1-10.

31. Trivedi MK, Branton A, Trivedi D, Nayak G, Mondal SC, et al. (2015) Morphological characterization, quality, yield and DNA fingerprinting of biofield energy treated alphonso mango (Mangifera indica L.). Journal of Food and Nutrition Sciences 3(6): 245-250. 
32. Trivedi MK, Branton A, Trivedi D, Nayak G, Mondal SC, et al. (2015) Evaluation of biochemical marker - Glutathione and DNA fingerprinting of biofield energy treated Oryza sativa. American Journal of Bio Science 3: 243-248.

33. Trivedi MK, Patil S, Shettigar H, Mondal SC, Jana S (2015) Evaluation of biofield modality on viral load of Hepatitis B and C viruses. J Antivir Antiretrovir 7: 83-88.

34. Trivedi MK, Patil S, Shettigar H, Mondal SC, Jana S (2015) An impact of biofield treatment: antimycobacterial susceptibility potential using BACTEC 460/MGIT-TB System. Mycobact Dis 5(4): 189.

35. Trivedi MK, Branton A, Trivedi D, Nayak G, Charan S, et al. (2015) Phenotyping and 16S rDNA analysis after biofield treatment on Citrobacter braakii: A urinary pathogen. J Clin Med Genom 3: 129.

36. Trivedi MK, Branton A, Trivedi D, Nayak G, Mondal SC, et al. (2015) Effect of biofield treated energized water on the growth and health status in chicken (Gallus gallusdomesticus). Poult Fish WildISci 3: 140.

37. Trivedi MK, Branton A, Trivedi D, Shettigar H, Bairwa K, et al. (2015) Fourier transform infrared and ultraviolet-visible spectroscopic characterization of biofield treated salicylic acid and sparfloxacin. Nat Prod Chem Res 3: 186.

38. Trivedi MK, Branton A, Trivedi D, Nayak G, Nykvist CD, et al. (2017) Evaluation of the trivedi effect ${ }^{\circledR}$-energy of consciousness energy healing treatment on the physical, spectral, and thermal properties of zinc chloride. American Journal of Life Sciences 5: 11-20.

39. Trivedi MK, Patil S, Shettigar H, Bairwa K, Jana S (2015) Spectroscopic characterization of biofield treated metronidazole and tinidazole. Med chem 5: 340-344

40. Trivedi MK, Sethi KK, Panda P, Jana S (2017) Physicochemical, thermal and spectroscopic characterization of sodium selenate using XRD, PSD, DSC, TGA/DTG, UV-vis, and FT-IR. Marmara Pharmaceutical Journal 21(2): 311-318.

41. Trivedi MK, Sethi KK, Panda P, Jana S (2017) A comprehensive physicochemical, thermal, and spectroscopic characterization of zinc (II) chloride using X-ray diffraction, particle size distribution, differential scanning calorimetry, thermogravimetric analysis differential thermogravimetric analysis, ultraviolet-visible, and fourier transform-infrared spectroscopy. International Journal of Pharmaceutical Investigation 7(1): 33-40.

42. Zhang T, Paluch K, Scalabrino G, Frankish N, Healy AM, et al. (2015) Molecular structure studies of (1S,2S)-2-benzyl-2,3-dihydro-2(1Hinden-2-yl)-1H-inden-1-ol. J Mol Struct 1083: 286-299.

43. (1997) Desktop X-ray diffractometer "Mini flex+". The Rigaku Journal 14: $29-36$

44. Langford JI, Wilson AJC (1978) Scherrer after sixty years: a survey and some new results in the determination of crystallite size. J Appl Cryst 11: 102-113.

45. Loh ZH, Samanta AK, Heng PWS (2015) Overview of milling techniques for improving the solubility of poorly water-soluble drugs. Asian J Pharm 10(4): 255-274.

46. Khadkaa P, Roa J, Kim H, Kim I, Kim JT, et al. (2014) Pharmaceutical particle technologies: An approach to improve drug solubility, dissolution and bioavailability. Asian J Pharm 9(6): 304-316.

47. Hu J, Johnston KP, Williams RO (2004) Nanoparticle engineering processes for enhancing the dissolution rates of poorly water-soluble drugs. Drug Dev Ind Pharm 30(3): 233-245.

48. Trivedi MK, Branton A, Trivedi D, Nayak G, Lee AC, et al. (2017) Evaluation of the impact of biofield energy healing treatment (the Trivedi Effect ${ }^{\circledR}$ ) on the physicochemical, thermal, structural, and behavioural properties of magnesium gluconate. International Journal of Nutrition and Food Sciences 6(2): 71-82.

49. Trivedi MK, Branton A, Trivedi D, Nayak G, Plikerd WD, et al. (2017) Evaluation of the physicochemical, spectral, thermal and behavioral properties of sodium selenate: Influence of the energy of consciousness healing treatment. American Journal of Quantum Chemistry and Molecular Spectroscopy 2(2): 18-27.

50. Savjani KT, Gajjar AK, Savjani JK (2012) Drug solubility: importance and enhancement techniques. ISRN Pharmaceutics, 2012: Article ID 195727. 